\title{
Side-Effects of Glyphosate to the Parasitoid Telenomus remus Nixon (Hymenoptera: Platygastridae)
}

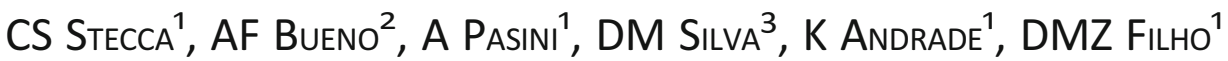 \\ ${ }^{1}$ Univ Estadual de Londrina - UEL, Londrina, PR, Brasil \\ ${ }^{2}$ Empresa Brasileira de Pesquisa Agropecuária - Embrapa Soja, Caxia Postal 231, Londrina, PR, Brasil \\ ${ }^{3}$ Instituto Agrônomico do Paraná - IAPAR, Londrina, PR, Brasil
}

\section{Keywords}

Biological control, herbicide, integrated pest management, transgenerational effects

\section{Correspondence}

AF Bueno, Empresa Brasileira de Pesquisa Agropecuária - Embrapa Soja, Rod. Carlos João Strass - Distrito de Warta, Caxia Postal 231, 86001-970 Londrina, PR, Brasil; adeney.bueno@embrapa.br

Edited by Moisés J Zotti - UFPel

Received 30 March 2015 and accepted 3 January 2016

Published online: 3 February 2016

(C) Sociedade Entomológica do Brasil 2016

\begin{abstract}
The aim of this study was to compare the side-effects of glyphosate to the parasitoid Telenomus remus Nixon (Hymenoptera: Platygastridae) when parasitoids were exposed to this chemical at the pupal (inside host eggs) and adult stages. Bioassays were conducted under laboratory conditions according to the International Organization for Biological Control (IOBC) standard methods for testing side-effects of pesticides to egg parasitoids. Different glyphosate-based pesticides (Roundup Original ${ }^{\circledR}$, Roundup Ready ${ }^{\circledR}$, Roundup Transorb ${ }^{\circledR}$, Roundup WG ${ }^{\circledR}$, and Zapp Q ${ }^{\circledR}$ ) were tested at the same acid equivalent concentration. Treatments were classified following the IOBC toxicity categories as (1) harmless, (2) slightly harmful, (3) moderately harmful, and (4) harmful. When tested against $T$. remus adults, Roundup Original ${ }^{\circledR}$, Roundup Ready ${ }^{\circledR}$, Roundup Transorb ${ }^{\circledR}$, and Roundup WG ${ }^{\circledR}$ reduced parasitism 2 days after parasitoid emergence, being classified as slightly harmful. Differently, when tested against $T$. remus pupae, all tested glyphosate-based products did not differ in their lethal effect and therefore did not reduce $T$. remus adult emergence or parasitism capacity, being classified as harmless. However, differences on sublethal toxicity were found. Parasitism of individuals emerging from parasitized eggs sprayed at the pupal stage of $T$. remus with Zapp Q ${ }^{\circledR}$ was lower compared to control, but parasitism was still higher than $66 \%$, and therefore, Zapp Q ${ }^{\circledR}$ was still classified as harmless. In conclusion, all tested glyphosate-based products can be used in agriculture without negative impact to $T$. remus as none was classified as harmful or moderately harmful to this parasitoid when exposure occurred at the pupal or adult stages.
\end{abstract}

\section{Introduction}

Glyphosate inhibits the EPSP synthase enzyme (5enolpyruvylshikimate 3-phosphate synthase) (Coutinho \& Mazo 2005) and is today one of the most widely used herbicides throughout the world, mainly due to its broad-spectrum weed control (Travlos \& Chachalis 2013, Shrestha et al 2014).
Spraying with this herbicide has become the main strategy of weed control in genetically engineered crops like soybean, maize, and cotton that carry resistant traits against this molecule. Glyphosate helps to prevent weed competition (Shaner 2000) that can reduce agricultural production by 30 to $40 \%$ (Lorenzi 2000). The classification of glyphosate as an herbicide does not account for its effects on beneficial organisms. Even 
though it is applied exclusively for weed control, it can impact non-target organisms, such as insects (Rizzardi et al 2003).

Pesticide risk assessment has usually been based on shortterm acute toxicity effects (lethal effects). Longer-term effects on population dynamics (sublethal effects), critical for biological control, and consequently, the success of integrated pest management (IPM) are often overlooked (Biondi et al 2013). However, sublethal effects of a given compound are also related to its toxicological properties acting on arthropod physiology and behavior (Biondi et al 2012). It has been pointed out that acute toxicity assessments alone cannot fully predict the actual impact of pesticides on non-target organisms (Ali et al 2012, Tan et al 2012, Guo et al 2013, Kim et al 2013, Planes et al 2013, Saber \& Abedi 2013, Sohrabi et al 2013).

Sublethal effects related to species-specific life history traits must be carefully considered in order to assess pesticide risks to IPM programs (Biondi et al 2013). These effects are defined as physiological and/or behavioral effects on individuals that survive exposure to a toxic compound at low concentrations (Desneux et al 2007) and may be expressed as changes in the life history traits of a beneficial insect species, such as parasitoid-regarded parasitism rate, longevity, egg viability, consumption rate, and behavioral patterns (Croft 1990, Desneux et al 2007).

Among different species, the egg parasitoid Telenomus remus Nixon (Hymenoptera: Platygastridae) is an effective biological control agent for various pest species of the genus Spodoptera (Cave 2000, Morales et al 2000, Pomari et al 2012), mainly due to its high reproductive capacity (Bueno et al 2008). Its hosts include Spodoptera frugiperda (J.E. Smith), Spodoptera eridania (Cramer), and Spodoptera cosmioides (Walker) (Lepidoptera: Noctuidae), responsible for heavy production losses in soybean, maize, and cotton crops (Cruz et al 1999, Carmo et al 2009, Santos et al 2010). The parasitoid $T$. remus has been used extensively in pest management programs in Venezuela involving inundative release in maize-growing areas (Hernández et al 1989, González \& Zocco 1996, Ferrer 2001). Inundative biological control aims at directly increasing mortality of the pest population, whereby the released natural enemy is used as a biological insecticide (Stinner 1977). The practice of inundative release therefore centers on its cost/benefit ratio as compared to other alternatives, especially pesticides.

Therefore, releasing but also preserving this egg parasitoid in agroecosystems where it naturally occurs is a very important step toward suppressing populations of Spodoptera spp. below levels that cause economic losses (Carmo et al 2010a). However, the use of herbicides for weed control might also be necessary and, in some situations, weed and pest control need to be applied simultaneously. Then, knowledge on the parasitization ability of this parasitoid after glyphosate exposure is of crucial importance to classify the side-effects of this herbicide on the egg parasitoid $T$. remus and select the most selective ones.

The glyphosate toxicity can be due to the chemical action of its active ingredient, which may be toxic to small insects such as Trichogramma (Bueno et al 2008). However, glyphosate sublethal toxicity on egg parasitoids may differ among products (Giolo et al 2005, Nörnberg et al 2008). Each of these products has a slightly different chemistry and surfactant mixture, and in comparison with the original Roundup formulation (Roundup Original ${ }^{\circledR}$ ), some of these products might be less acutely toxic to non-target organisms (Howe et al 2004). It is therefore important to understand the chemical properties of glyphosate and its different glyphosate-based products as well as its lethal and sublethal toxicity to beneficial insects in order to point the most harmless glyphosate to beneficial insects to be used in IPM crops. Although there is information in the literature on the physical, chemical, and toxicological properties of glyphosate (Amarante Júnior et al 2002), little is known about the toxicity of different commercial glyphosate-based products to beneficial insects (Giolo et al 2005, Bueno et al 2008, Nörnberg et al 2008, Carmo et al 2009) and a diversity of glyphosate brands is available. These products are based on a variety of salts, such as potassium salt, isopropylamine salt, and ammonium salt, which, despite having the same mechanism of action, may have different effects on beneficial organisms (Giolo et al 2005). Therefore, the aim with this study was to comparatively assess lethal and sublethal effects of different glyphosate-based products applied to $T$. remus pupae (within host eggs) and on parasitoid adults emerged from these treated pupae. We also evaluated the parasitism activity of adults (emerged from non-treated pupae) directly exposed to dry residue on inert substrate as well as the transgenerational effect on the adult emergence of the $F_{1}$ generation (i.e., progeny of the treated generation).

\section{Material and Methods}

The bioassays were conducted in the laboratory under controlled conditions $\left(25 \pm 2{ }^{\circ} \mathrm{C}, 70 \pm 10 \% \mathrm{RH}, 14 \mathrm{~L}: 10 \mathrm{D} \mathrm{h}\right.$ photoperiod) in a fully randomized arrangement, with seven treatments and five replications, in accordance with the protocols proposed by Pesticides and Beneficial Organisms from the International Organisation for Biological Control (IOBC) (Hassan et al 2000, Manzoni et al 2007) and modified by Carmo et al (2010a) for studies with T. remus.

All tested glyphosate-based commercial products were adjusted to a concentration recommended for postemergence application on plants. Furthermore, all treatments were set at the same acid equivalent concentration ( $720 \mathrm{~g} \mathrm{ha}^{-1}$ ) considering $200 \mathrm{~L}$ of water ha ${ }^{-1}$ to obtain a better 
understanding of possible lethal and sublethal effects of different commercial brands and their chemical differences on the studied parasitoid. The studied treatments were (1) negative control (distilled water); (2) Roundup Original ${ }^{\circledR}$, isopropylamine salt, $960 \mathrm{~g}$ of active ingredient (a.i.) $\mathrm{ha}^{-1} ;$ (3) Roundup Ready ${ }^{\circledast}$, isopropylamine salt, $972 \mathrm{~g}$ a.i. ha ${ }^{-1}$; (4) Roundup Transorb ${ }^{\circledR}$, isopropylamine salt, $972 \mathrm{~g}^{2}$ a.i. $\mathrm{ha}^{-1} ;$ (5) Roundup WG ${ }^{\circledR}$, ammonium salt, $792.5 \mathrm{~g}^{2}$ a.i. ha ${ }^{-1}$; (6) Zapp $\mathrm{Qi}^{\oplus}$, potassium salt, $892.8 \mathrm{~g}$ a.i. ha $^{-1}$; and (7) positive control (Lorsban ${ }^{\circledR} 480 \mathrm{BR}$ ), chlorpyrifos $480 \mathrm{~g}$ a.i. ha ${ }^{-1}$. The active ingredient and dosage of the positive control were defined according to Carmo et al (2010a, b) who showed this treatment to be harmful to both $T$. remus pupae and adults.

\section{Parasitoid and host colonies}

All $S$. frugiperda eggs and $T$. remus used in the experiments were obtained from insect colonies kept at Embrapa Soybean, located in Londrina, state of Paraná, Brazil. Spodoptera frugiperda was originally collected on corn plants (Zea mays) in Rio Verde, state of Goiás, in 2007. After field collection, it was reared under laboratory-controlled environmental conditions $\left(25 \pm 2^{\circ} \mathrm{C} 70 \pm 10 \% \mathrm{RH}\right.$, and $14 \mathrm{~L}: 10 \mathrm{D} \mathrm{h}$ photoperiod) and fed on the artificial diet proposed by Greene et al (1976) and Parra (2001) for about 136 generations. Telenomus remus was originally collected in Ecuador and was multiplied at the parasitoid-rearing facilities at ESALQ/USP (Escola Superior de Agricultura "Luiz de Queiroz"/Universidade de São Paulo), from where some specimens were transferred to Embrapa Soybean 8 years ago. Since then, $T$. remus has been reared in the laboratory using $S$. frugiperda egg masses (approximately 150 eggs each) for about 250 generations. These egg masses were glued onto a cardboard sheet $(2 \mathrm{~cm} \times 8 \mathrm{~cm})$. Three of these sheets with eggs previously parasitized by $T$. remus were placed in a glass tube ( $8 \mathrm{~cm}$ long and $2 \mathrm{~cm}$ in diameter) sealed with a PVC film. Small drops of honey were placed in these tubes to feed the adults when they emerged. These tubes, containing the parasitoids, were then closed, and T. remus parasitism was allowed for $24 \mathrm{~h}$. Adults emerging from these eggs were used for experiments or for colony maintenance. Quality control of the parasitoid colony was evaluated in accordance with Prezotti et al (2002) who performed each 10 generations of the insect, and endogamy issues were never observed.

\section{Adult parasitoid side-effect bioassay}

Spodoptera frugiperda eggs parasitized by $T$. remus $( \pm 250$ pupae of $T$. remus) were placed in Duran tubes containing a drop of honey and sealed with a plastic film. They were kept in a controlled environment $\left(25 \pm 2^{\circ} \mathrm{C}, 70 \pm 10 \% \mathrm{RH}\right.$, a photoperiod of 14:10 $\mathrm{h}$ L/D) until parasitoids emerged. Up to $24 \mathrm{~h}$ after the emergence of $T$. remus adults inside the tubes, glass plates $(13 \times 13 \mathrm{~cm})$ were sprayed with the described treatments using a Potter tower calibrated to deposit $1.75 \pm 0.25 \mathrm{mg}$ solution $\mathrm{cm}^{-2}$ (Hassan et al 2000, Manzoni et al 2007). The volume of application was controlled using a precision electronic balance both before and after spraying (Carmo et al 2010a).

After spraying, plates were left to dry for $2 \mathrm{~h}$ at $25 \pm 2^{\circ} \mathrm{C}$, $70 \pm 10 \% \mathrm{RH}$, under constant illumination. Next, the plates were fixed into aluminum frames with forced air circulation using an extractor (Hassan 1992). After setting up the plates in the air flow, the Duran tubes containing the parasitoids (around 200 adults with a sex ratio of $0.6,80 \%$ of the 250 pupae selected) were wrapped in aluminum foil and linked up to the emergence holes (Carmo et al 2010a). One day after adult release, the Duran tube was removed while visually ensuring that all parasitoids entered the arena (more than $90 \%$ of the replicates). When only a few parasitoids were left in the Duran tube, they were manually forced into the arena.

Twenty-four hours after parasitoid release into the arenas, numbered cards, containing $S$. frugiperda egg masses (300 \pm 100 eggs) and honey droplets, were inserted. A second card was placed inside each cage $24 \mathrm{~h}$ after the first card. Since superparasitism is rare for this species (Cave 2000), the first card was not removed from the cages because parasitoids tend to stay on the top and middle egg masses so that, inevitably, some test organisms would have been removed with this first card. Since eggs were not sterile, as used in Trichogramma selectivity tests, in order to avoid any change in the behavior of $T$. remus, the experiments had to be stopped on the third day to prevent $S$. frugiperda from hatching (Carmo et al 2010a). The cards were removed from the enclosures and placed in transparent plastic bags which were then stored at $25 \pm 2^{\circ} \mathrm{C}, 70 \pm 10 \% \mathrm{RH}$, and a photoperiod of $14: 10 \mathrm{~h} \mathrm{~L} / \mathrm{D}$ until emergence of the parasitoids so that parasitism could be assessed.

\section{Side-effects to pupal parasitoid bioassay}

Cards with $300 \pm 100 S$. frugiperda eggs with $T$. remus pupae close to emergence (11 days after parasitism) were kept at $25^{\circ} \mathrm{C}$ under a 14:10 h L/D photoperiod (Pomari et al 2012) and were sprayed with the treatments previously described. Since there is no superparasitism in this parasitoid species (Pomari et al 2012), the number of parasitoid pupae was estimated by counting the number of parasitized $S$. frugiperda eggs under a stereoscopic microscope.

As in the adult bioassay, spraying was carried out using a Potter tower calibrated to deposit $1.75 \pm 0.25 \mathrm{mg} \mathrm{cm}^{-2}$ solution, in line with IOBC standards (Hassan 1992). Next, sprayed eggs containing $T$. remus pupae were kept at $25 \pm 2^{\circ} \mathrm{C}, 70$ $\pm 10 \% \mathrm{RH}$, for around $2 \mathrm{~h}$ under constant illumination to 
eliminate excess moisture. Treated cards were then inserted into enclosures as described for the adult bioassay (Hassan 1992) until adults emerged (generation $F_{0}$ ). Honey droplets on small cards were inserted into the cage to feed the adults after emergence. Cards with S. frugiperda eggs (300 \pm 100 eggs up to $24 \mathrm{~h}$ old) were offered 1 and 2 days after adults emerged. On the third day, the cards were stored in air-filled plastic bags until evaluation. Viability of the sprayed pupae (number of parasitized eggs with a parasitoid emergence hole), parasitism capacity of the $\mathrm{F}_{\mathrm{o}}$ generation (adults originating from treated pupae), and transgenerational effects on the percentage of emergence of the $F_{1}$ generation (progeny of the treated generation) were quantified.

\section{Statistical analysis}

The results were subjected to exploratory analysis to evaluate normality assumptions for the residues (Shapiro \& Wilk 1965), homogeneity of the variance between treatments (Burr \& Foster 1972), and additivity of the model in order to apply an analysis of variance (ANOVA). Data not following the normality assumptions or homogeneity of variance were transformed to $\arcsin \sqrt{X / 100}$. This transformation was performed for viability (\%) at both the second day of herbicide contact [ 2 days after parasitoid emergence (DAE)] for both adult and pupal trials. Means were compared using Tukey's honest significant difference (HSD) test ( $5 \%$ error probability) implemented in the SAS statistical analysis program (SAS Institute 2001).

In addition, the effect $(E)$ of each pesticide on $T$. remus was determined by comparison with a negative control (distilled water) and calculated using the formula by Hassan et al (1985, 2000) and Carmo et al (2010a): $E_{1} \%=(1-$ parasitism in the treatment / parasitism in the control) $\times 100$ for adult assays and $E_{2} \%=(1-$ viability of sprayed pupae / viability of pupae treated with the control) $\times 100$ for pupal assays. Treatments were classified as follows: class $1=$ harmless $(E<30 \%)$, class $2=$ slightly harmful $(30 \% \leq E<80)$, class $3=$ moderately harmful $(80 \% \leq E<99)$, and class $4=$ harmful $(E \geq 99 \%)$.

\section{Results}

\section{Adult parasitoid side-effect bioassay}

When glyphosate was tested for $T$. remus adults, parasitism (\%) was not affected by the tested glyphosate-based products on the first day after adult emergence (1 DAE) and, therefore, none of the glyphosate-based products differed from the negative control (Table 1) being classified as harmless (class 1) (Table 3). Differently, 2 DAE, Roundup Original ${ }^{\circledR}$,
Roundup Ready ${ }^{\circledR}$, Roundup Transorb ${ }^{\circledR}$, and Roundup WG ${ }^{\circledR}$ reduced parasitism compared to negative control (Table 1), being classified as slightly harmful (class 2) (Table 3). At 2 DAE, Zapp Qi ${ }^{\circledR}$ was the only tested treatment to be classified as harmless (class 1) (Table 3 ).

Parasitoid viability by comparison with the negative control (water) was not altered by the application of any of the glyphosate treatments in the daily evaluations at both 1 and 2 DAE (Table 1). In contrast, for the chlorpyrifos insecticide (positive control), there was no parasitism on the days assessed (Table 1).

\section{Side-effects to pupal parasitoid bioassay}

Similar to the results reported for adults, the assessed glyphosate-based products did not differ in their effect on parasitoid emergence from sprayed pupae (Table 2). Furthermore, parasitism of generation $\mathrm{F}_{\mathrm{O}}$ and viability of generation $F_{1}$ glyphosate-based products did not differ among each other or from the control (distilled water), with the exception of Zapp $\mathrm{Q} \mathrm{i}^{\circledR}$. In the latter treatment, we recorded the lowest 1 DAE parasitism, although this was not observed on 2 DAE (Table 2).

All glyphosate treatments were classified as harmless (class 1) (Hassan et al 1985) at the pupal development stage of the parasitoid (Table 3 ). However, the positive control (chlorpyrifos) differed from the negative control (distilled water) and the glyphosate treatments. It adversely affected parasitism and emergence of adults (Table 2 ) and was classified as harmful (class 4) at this stage of development of T. remus (Hassan et al 1985) (Table 3).

\section{Discussion}

In general, glyphosate did not severely impact the egg parasitoid $T$. remus. These results might be due to its mode of action. Glyphosate is a non-selective herbicide that inhibits plant growth through interference with the production of essential aromatic amino acids by inhibition of the enzyme enolpyruvylshikimate phosphate synthase. This enzyme is responsible for the biosynthesis of chorismate, an intermediate in phenylalanine, tyrosine, and tryptophan biosynthesis (Williams et al 2000). This pathway for aromatic amino acid biosynthesis is exclusive to plants; therefore, its blockage does not affect members of the animal kingdom, including beneficial arthropods (Williams et al 2000).

Despite this exclusive glyphosate action above plants, it is important to point out that commercial glyphosate products contain various other chemicals that may not be specified on the label. One of the reasons is that information regarding the surfactant components of herbicide formulations is often protected as proprietary information of the manufacturer 
Table 1 Impact of glyphosate and chlorpyrifos commercial products on parasitism activity and viability of Telenomus remus adults (emerged from non-treated pupae) directly exposed to dry residue on inert substrate 1 and 2 days after parasitoid emergence (DAE) $\left(25 \pm 2^{\circ} \mathrm{C}, 70 \pm 10 \% \mathrm{RH}\right.$, photoperiod of 14:10 h L/D).

\begin{tabular}{|c|c|c|c|c|}
\hline \multirow[t]{2}{*}{ Treatment } & \multicolumn{2}{|l|}{$1 \mathrm{DAE}$} & \multicolumn{2}{|l|}{2 DAE } \\
\hline & Parasitism (\%) & Viability (\%) & Parasitism (\%) & Viability (\%) ${ }^{\mathrm{a}}$ \\
\hline Control & $74.3 \pm 5.3 a$ & $60.3 \pm 8.8 \mathrm{~ns}$ & $81.3 \pm 6.4 a$ & $61.4 \pm 13.3 \mathrm{~ns}^{\mathrm{b}}$ \\
\hline Roundup Original $^{\circledR}$ & $70.0 \pm 5.6 \mathrm{a}$ & $79.7 \pm 5.1$ & $44.6 \pm 1.6 \mathrm{~b}$ & $80.2 \pm 2.7$ \\
\hline Roundup Ready ${ }^{\circledast}$ & $68.0 \pm 8.2 \mathrm{a}$ & $60.9 \pm 5.4$ & $25.3 \pm 4.5 \mathrm{C}$ & $52.3 \pm 14.2$ \\
\hline Roundup Transorb ${ }^{\circledR}$ & $74.7 \pm 6.0 \mathrm{a}$ & $70.4 \pm 10.2$ & $42.2 \pm 1.8 b$ & $64.6 \pm 16.3$ \\
\hline Roundup WG ${ }^{\circledR}$ & $69.9 \pm 6.8 \mathrm{a}$ & $65.6 \pm 3.3$ & $24.1 \pm 1.7 \mathrm{C}$ & $57.0 \pm 2.0$ \\
\hline Zapp Qi ${ }^{\circledR}$ & $53.0 \pm 9.4 \mathrm{a}$ & $61.4 \pm 13.1$ & $79.7 \pm 3.9 \mathrm{a}$ & $58.1 \pm 16.5$ \\
\hline Lorsban ${ }^{\circledast} 480$ BR & $0.0 \pm 0.0 \mathrm{~b}$ & - & $0.0 \pm 0.0 \mathrm{~d}$ & - \\
\hline CV (\%) & 24.87 & 28.59 & 17.56 & 33.70 \\
\hline$F$ & 17.05 & 0.70 & 79.52 & 0.34 \\
\hline$d f_{\text {total }}$ & 33 & 28 & 31 & 21 \\
\hline$p$ & $<0.0001$ & 0.6286 & $<0.0001$ & 0.8816 \\
\hline
\end{tabular}

ns = ANOVA is not significant; - = non-existent parameter.

${ }^{a}$ Means followed by the same letter in columns do not differ significantly (Tukey's HSD test, 5\% probability).

${ }^{\mathrm{b}}$ Original results followed by statistical analysis of the data transformed to $\arcsin \sqrt{X / 100}$.

(Chen et al 2004). These other components can carry their own toxicity and are reported to trigger harmful side-effects in some egg parasitoids (Nörnberg et al 2008). In larval amphibians, glyphosate-based products containing a common surfactant, polyethoxylated tallowamine (POEA), have been classified as moderately to highly toxic in laboratory, mesocosm, and pond enclosure experiments (Chen et al 2004). However, chemical side-effects above natural enemies might vary accordingly to the studied biological control species, indicating the importance of studying different parasitoid species, including $T$. remus. Previous results had shown noxious effects of some glyphosate-based herbicides on the egg parasitoid species Trichogramma pretiosum Riley (Hymenoptera: Trichogrammatidae) (Nörnberg et al 2008) what was not observed at the same degree of intensity for $T$. remus in our study.

Differences among glyphosate-based products for T. remus were observed for adult parasitoids $2 \mathrm{DAE}$ (Table 1) and on parasitism 1 DAE of adults from sprayed pupae (Table 3). Differences for adult parasitoid (Table 1)

Table 2 Impact of glyphosate and chlorpyrifos commercial products on Telenomus remus pupae (inside host eggs) and on parasitoid adults emerged from treated pupae 1 and 2 days after emergence (DAE) $\left(25 \pm 2^{\circ} \mathrm{C}, 70 \pm 10 \% \mathrm{RH}\right.$, photoperiod of 14:10 $\left.\mathrm{h} \mathrm{L} / \mathrm{D}\right)$.

\begin{tabular}{|c|c|c|c|c|c|}
\hline Treatment & $\begin{array}{l}\text { Sprayed pupae } \\
\text { Viability }(\%)^{a}\end{array}$ & $\begin{array}{l}\text { Generation } F_{O}(1 \mathrm{DAE}) \\
\text { Parasitism }(\%)^{\mathrm{a}}\end{array}$ & $\begin{array}{l}\text { Generation } \mathrm{F}_{1}(1 \mathrm{DAE}) \\
\text { Viability }(\%)^{\mathrm{a}}\end{array}$ & $\begin{array}{l}\text { Generation } \mathrm{F}_{\mathrm{O}}(2 \mathrm{DAE}) \\
{\text { Parasitism }(\%)^{\mathrm{a}}}\end{array}$ & 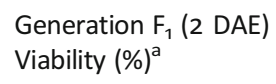 \\
\hline Control & $98.4 \pm 0.8 a$ & $88.6 \pm 6.0 \mathrm{a}$ & $84.8 \pm 5.5 \mathrm{~ns}$ & $72.5 \pm 5.3 a$ & $85.8 \pm 4.5 a b^{b}$ \\
\hline Roundup Original $^{\circledR}$ & $96.3 \pm 1.3 \mathrm{a}$ & $86.9 \pm 4.6 \mathrm{ab}$ & $85.4 \pm 4.2$ & $68.0 \pm 9.1 \mathrm{a}$ & $80.8 \pm 4.4 b$ \\
\hline Roundup Ready ${ }^{\circledast}$ & $98.1 \pm 0.7 \mathrm{a}$ & $84.5 \pm 2.8 \mathrm{ab}$ & $82.3 \pm 6.0$ & $66.2 \pm 6.9 \mathrm{a}$ & $97.0 \pm 2.2 \mathrm{a}$ \\
\hline Roundup Transorb ${ }^{\circledR}$ & $96.1 \pm 0.7$ a & $87.4 \pm 6.5 a b$ & $92.3 \pm 2.7$ & $81.7 \pm 5.8 \mathrm{a}$ & $92.7 \pm 2.4 a b$ \\
\hline Roundup WG ${ }^{\circledR}$ & $96.3 \pm 0.9$ a & $84.6 \pm 4.0 \mathrm{ab}$ & $95.8 \pm 2.7$ & $68.1 \pm 5.9 \mathrm{a}$ & $95.6 \pm 1.4 a b$ \\
\hline Zapp Qi ${ }^{\circledast}$ & $98.3 \pm 0.5 a$ & $66.5 \pm 5.1 b$ & $91.3 \pm 3.9$ & $80.9 \pm 5.2 \mathrm{a}$ & $88.0 \pm 4.5 a b$ \\
\hline Lorsban ${ }^{\circledast} 480$ BR & $0.3 \pm 0.2 \mathrm{~b}$ & $0.0 \pm 0.0 \mathrm{c}$ & - & $0.0 \pm 0.0 \mathrm{~b}$ & - \\
\hline CV (\%) & 2.06 & 14.22 & 10.94 & 21.54 & 9.89 \\
\hline$F$ & 2274.09 & 51.65 & 1.47 & 22.02 & 3.64 \\
\hline$d f_{\text {total }}$ & 34 & 31 & 29 & 34 & 27 \\
\hline$p$ & $<0.0001$ & $<0.0001$ & 0.2377 & $<0.0001$ & 0.0150 \\
\hline
\end{tabular}

Generation $F_{0}$ is parasitoids originated from sprayed pupae. Generation $F_{1}$ is parasitoids from Generation $F_{0}$. $-=$ non-existent parameter.

${ }^{a}$ Means followed by the same letter in columns do not differ significantly (Tukey's HSD test, $5 \%$ probability).

${ }^{b}$ Original results followed by statistical analysis of the data transformed to $\arcsin \sqrt{X / 100}$. 
Table 3 Effect $(E)$ of each of glyphosate and chlorpyrifos commercial product to Telenomus remus, followed by the classification of the product toxicology (C) according to the standards of the International Organization for Biological Control (IOBC) $\left(25 \pm 2^{\circ} \mathrm{C}, 70 \pm 10 \% \mathrm{RH}\right.$, photoperiod of $\left.14: 10 \mathrm{~h} \mathrm{L/D}\right)$.

\begin{tabular}{|c|c|c|c|c|c|c|c|c|c|c|}
\hline \multirow[t]{3}{*}{ Treatment } & \multicolumn{4}{|c|}{ Adults } & \multirow{2}{*}{\multicolumn{2}{|c|}{ Sprayed pupae }} & \multicolumn{4}{|c|}{ Generation $\mathrm{F}_{\mathrm{o}}$} \\
\hline & \multicolumn{2}{|c|}{$1 \mathrm{DAE}$} & \multicolumn{2}{|c|}{$2 \mathrm{DAE}$} & & & \multicolumn{2}{|c|}{$1 \mathrm{DAE}$} & \multicolumn{2}{|c|}{$2 \mathrm{DAE}$} \\
\hline & $E_{1} \%^{\mathrm{a}}$ & $c^{b}$ & $E_{1} \%^{\mathrm{a}}$ & $c^{b}$ & $E_{2} \%^{\mathrm{c}}$ & $c^{b}$ & $E_{1} \%^{\mathrm{a}}$ & $C^{b}$ & $E_{1} \%^{\mathrm{a}}$ & $c^{b}$ \\
\hline Roundup Original $^{\circledR}$ & 5.8 & 1 & 45.2 & 2 & 2.1 & 1 & 1.9 & 1 & 6.2 & 1 \\
\hline Roundup Ready ${ }^{\circledast}$ & 8.5 & 1 & 68.9 & 2 & 0.3 & 1 & 4.6 & 1 & 8.8 & 1 \\
\hline Roundup Transorb ${ }^{\circledR}$ & 0 & 1 & 48.1 & 2 & 2.3 & 1 & 1.4 & 1 & 0 & 1 \\
\hline Roundup WG ${ }^{\circledR}$ & 6.0 & 1 & 70.4 & 2 & 2.1 & 1 & 4.5 & 1 & 6.1 & 1 \\
\hline Zapp Qi ${ }^{\circledR}$ & 28.6 & 1 & 2.1 & 1 & 0.0 & 1 & 25.0 & 1 & 0 & 1 \\
\hline Lorsban ${ }^{\circledast} 480$ BR & 100 & 4 & 100 & 4 & 99.7 & 4 & 100 & 4 & 100 & 4 \\
\hline
\end{tabular}

${ }^{\mathrm{a}}$ Effect $(E)$ of each pesticide on adults: $E_{1} \%=(1-$ parasitism of the treatment / parasitism of the control) $\times 100$ (Hassan et al 1985).

${ }^{\mathrm{b}}$ Classification: class $1=$ harmless $(E<30 \%)$, class $2=$ slightly harmful $(30 \% \leq E<80)$, class $3=$ moderately harmful $(80 \% \leq E<99)$, and class $4=$ harmful $(E \geq 99 \%)$.

${ }^{\mathrm{c}}$ Effect $(E)$ of each pesticide on pupae: $E_{2} \%=(1-$ viability of pupae sprayed with the treatment / viability of pupae for the control $) \times 100($ Carmo et al 2010a).

are probably due to the fact that, at this stage of development, the insect is more susceptible to pesticides when exposed to contamination by contact when moving on treated surfaces (Hassan 1992, Bacci et al 2001). Differently, the pupa is protected inside the chorion of the host egg and is usually reported as more tolerant to chemicals (Hassan 1992) if compared to the adult stage. However, low parasitism 1 DAE of adults emerged from host eggs containing the parasitoid pupae sprayed with Zapp Q ${ }^{\circledR}$ (generation $F_{0}$ ) (Table 2) might indicate an effect of this commercial product on parasitoid emergence, leading to a delay in the beginning of parasitism by females if compared to other treatments. A delay on parasitism might also be explained by a period of detoxification, when parasitoids used its energy to circumvent any possible chemical damage instead of using energy to search for new eggs. However, the explanation for such effects and validation of these hypotheses still need investigation. It is important to point out that protection offered by the host egg to the parasitoid pupa strongly depends on chorion permeability, which differs among host species (Biondi et al 2012) and might be different for each chemical.

Host egg chorion must provide protection against external changes and also have the necessary texture and hardness to be accepted by $T$. remus females. Shape, size, and chorionic structure of host eggs can differ widely among species and are key factors in the host selection process for various parasitoid species (Salt 1938, Schmidt \& Smith 1987, Pak et al 1990, Schmidt 1994). Spodoptera frugiperda eggs have a moderate number of aeropyles located at the intersection between bridges and ridges. Their chorion is 2.50 to $11.95 \mu \mathrm{m}$ thick, forming a discontinuous mucous layer (Cônsoli et al 1999). Differences in thickness of the chorion, particularly the exochorion (the most protein-rich layer), can affect parasitism (Pak et al 1990) as well as oxygen balance with the environment (Hinton 1981), influencing, therefore, the permeability of the host egg after pesticide application. Thus, our data may be different from other host species. These differences might be related to sensitivity of host eggs to external changes which appears to heighten with an increasing number of aeropyle openings and to decrease with an increasing thickness of the mucous layer (Cônsoli et al 1999) that can be presented by different host species. Such effects of the relationship between chorion structure and host egg sensitivity on the provision of shelter to parasitoid development have been reported for many species of Lepidoptera (Barbier \& Chauvin 1974, Chauvin \& Chauvin 1980) and might play an important role in lethal and sublethal effects of pesticide application on immature parasitoid stages. These might explain differences among parasitoid species. However, a difference among chemicals in the same species is probably due to different toxicological properties of each pesticide (van der Werf 1996, Wijnands 1997). Differences in glyphosate-based products include different salts and surfactants used in the formulation of commercial brands. Salt formulations include isopropylamine, diammonium, monoammonium, or potassium as counterions. Also, glyphosate-based herbicides can be formulated with glyphosate either alone or with added cationic surfactants. The most common surfactant is polyethoxylated tallow referred to as polyoxyethyleneamine (POEA). Much of the available information reveals that endued (formulated) glyphosate products are more toxic to aquatic organisms than the glyphosate acid active ingredient alone and the results from the toxicity of the surfactant used in the formulation (Giesy et al 2000). It has also been shown that the toxicity of the surfactant varies with temperature, $\mathrm{pH}$, 
species, and stage of the animal exposed (Folmar et al 1979). In addition to differences in acute toxicity (Mann \& Bidwell 1999), several non-ionic surfactants (i.e., nonyl- and octylphenols) may act as endocrine-disrupting compounds (EDCs) and have shown estrogenicity in EDC assays (Routledge \& Sumpter 1996).

Small differences in the effect of glyphosate-based products may have remained undetected, especially when applied on pupae, considering that $T$. remus pupae might be better protected than adults and less sensitive to lethal and sublethal effects of pesticides. All glyphosate-based products were therefore classified as harmless (class 1 ) to the pupal stage of $T$. remus. This higher tolerance of pupae in comparison to adults has already been documented in the literature for other species of egg parasitoids (Giolo et al 2005, Nörnberg et al 2008), but this is the first time this phenomenon has been documented for T. remus. Moreover, the higher tolerance of pupae compared to adult can be sometimes less perceptible when product is harmful as what happened for chlorpyrifos.

In agreement with our findings for $T$. remus, lethal and sublethal effects of different glyphosate-based products on adults of $T$. pretiosum (Hymenoptera: Trichogrammatidae) were dependent on the salt present in the herbicide (Giolo et al 2005). Glyphosate-based products based on potassium (Zapp ${ }^{\circledR}$ Qi) and ammonium salts (Roundup ${ }^{\circledR}$ WG) were slightly harmful to T. pretiosum adults, causing 30 to $80 \%$ reduction in parasitism. The other glyphosate-based products based on isopropylamine salt (Roundup ${ }^{\circledR}$, Polaris ${ }^{\circledast}$, Gliz $^{\circledR} 480 \mathrm{CS}$, Glifosato Nortox ${ }^{\circledR}$, Glifosato 480 Agripec $^{\circledR}$, and Roundup ${ }^{\circledR}$ Transorb) were less selective (considering the different degrees of selectivity) to this beneficial insect and were classified as moderately harmful to adults of $T$. pretiosum, with 80 to $99 \%$ reduction in parasitism (Giolo et al 2005).

Chlorpyrifos was the most toxic treatment (classified as harmful) in all assessments and bioassays, as expected for a positive control (Tables 1 and 2). These negative effects of chlorpyrifos on $T$. remus were previously reported by Carmo et al (2009). This insecticide killed all parasitoid adults after entering the experimental arenas. When applied on pupae, $100 \%$ of the adults died as they attempted to emerge. Our data corroborate previous reports describing this pesticide as incompatible with the use of $T$. remus in biological control, whether in the adult or pupal stage. In general, neurotoxic compounds are less selective to natural enemies than others, like insect growth regulators (IGRs), for example. However, it is important to point out that the side-effects of IGR to natural enemies have been also reported in characteristics of the biology of many species with higher sensitivity in early stages of development (Cônsoli et al 2001). Insecticides that do not affect the survivorship of pre-imaginal stages of the parasitoid when the host eggs are treated could still reduce the capacity of parasitism of the adult parasitoid emerged (Cônsoli et al 1998). That is one of the reasons why insecticides must always be rationally used in agriculture according to the IPM guidance. In this context, it is helpful to explain that chlorpyrifos acts in the nervous system of the insects. Since the functioning of the nervous system and the enzymes involved in nerve pulse transmission processes is very similar to all arthropods, this insecticide is harmful to all insect species, whether pests or natural enemies. Therefore, the lack of selectivity of chlorpyrifos can be obviously explained by its mode of action on the nervous system of insects (Yu 1987).

It is important to take into consideration that when choosing an herbicide for crop treatment, glyphosate-based herbicides that are least harmful to natural enemies should be given priority. Therefore, bearing in mind the importance of using selective chemicals with low impact on beneficial arthropods, we can conclude that all tested glyphosate-based products can be used in agriculture without negative impact to $T$. remus since they were not classified as harmful or moderately harmful to when parasitoid was exposed at the pupal or adult stages even in the most extreme exposure assays under laboratory-controlled conditions.

Acknowledgments Thanks are extended to Dagmar Frisch for the English revision of this manuscript. This paper was approved for publication by the Editorial Board of Embrapa Soja. The authors would like to thank Embrapa Soja, the "Coordenação de Aperfeiçoamento de Pessoal de Nível Superior (CAPES)," and the "Conselho Nacional de Desenvolvimento Científico e Tecnológico" (CNPq), grant number 301420/2012-2, for funds that supported this research.

\section{References}

Ali A, Ahmad F, Biondi A (2012) Potential for using Datura alba leaf extracts against two major stored grain pests, the khapra beetle Trogoderma granarium and the rice weevil Sitophilus oryzae. J Pest Sci 85:359-366

Amarante Júnior OP, Santos TCR, Brito NM, Ribeiro ML (2002) Glifosato: propriedades, toxicidade, uso e legislação. Quim Nova 25:589-593

Bacci L, Picanço MC, Gusmão MR, Crespo ALB, Pereira EJG (2001) Seletividade de inseticidas a Brevicoryne brassicae (L.) (Hemiptera: Aphididae) e ao predador Doru luteipes (Scudder) (Dermaptera: Forficulidae). Neotrop Entomol 30:707-713

Barbier R, Chauvin G (1974) Ultrastructure et role des aeropyles et des envelopes de l'oeufs de Galleria mellonella. J Insect Physiol 20:809820

Biondi A, Monmaerts V, Smagghe G, Vinuela E, Zappala L, Desneux N (2012) The non-target impact of spinosyns on beneficial arthropods. Pest Manag Sci 68:1523-1536

Biondi A, Zappala L, Stark JD, Desneux N (2013) Do biopesticides affect the demographic traits of a parasitoid wasp and its biocontrol services through sublethal effects? PLoS ONE 8(9):e76548. doi:10.1371/ journal.pone. 0076548

Bueno AF, Bueno RCOF, Parra JRP, Vieira SS (2008) Effects of pesticides used in soybean crops to the egg parasitoid Trichogramma pretiosum. Cienc Rural 38:1495-1503

Burr IW, Foster LA (1972) A test for equality of variances. Mimeo series $n^{\circ} 282$. University of Purdue, West Lafayette, $26 p$ 
Carmo EL, Bueno AF, Bueno RCOF, Vieira SS, Gobbi AL, Vasco FR (2009) Seletividade de diferentes agrotóxicos usados na cultura da soja ao parasitoide de ovos Telenomus remus. Cienc Rural 39:2293-2300

Carmo EL, Bueno AF, Bueno RCOF (2010a) Pesticide selectivity for the insect egg parasitoid Telenomus remus. BioControl 55:455-464

Carmo EL, Bueno AF, Bueno RCOF, Vieira SS, Goulart MMP, Carneiro TR (2010b) Seletividade de produtos fitossanitários utilizados na cultura da soja para pupas de Trichogramma pretiosum Riley 1879 (Hymenoptera: Trichogrammatidae). Arq Inst Biol 77:283-290

Cave RD (2000) Biology, ecology and use in pest management of Telenomus remus. BioControl 21:21-26

Chauvin JT, Chauvin G (1980) Formation des reliefs externs de l'oeuf de Micropteryx caltella L. (Lepidoptera: Micropterigidae). Can J Zool 58: 761-766

Chen CY, Hathaway KM, Folt CL (2004) Multiple stress effects of vision 1 herbicide, $\mathrm{pH}$, and food on zooplankton and larval amphibian species from forest wetlands. Environ Toxicol Chem 23:823-831

Cônsoli FL, Parra J, Hassan S (1998) Side-effects of insecticides used in tomato fields on the egg parasitoid Trichogramma pretiosum Riley (Hym., Trichogrammatidae), a natural enemy of Tuta absoluta (Meyrick) (Lep., Gelechiidae). J Appl Entomol 122:43-47

Cônsoli FL, Kitajima EW, Parra JRP (1999) Ultrastructure of the natural and factitious host eggs of Trichogramma galloi Zucchi and Trichogramma pretiosum Riley (Hymenoptera: Trichogrammatidae). Int J Insect Morphol Embryol 28:211-231

Cônsoli FL, Botelho PSM, Parra JRP (2001) Selectivity of insecticides to egg parasitoid Trichogramma galloi Zucchi, 1988, (Hymenoptera: Trichogrammatidae). J Appl Entomol 125:37-43

Coutinho CFB, Mazo LH (2005) Complexos metálicos com o herbicida glifosato: revisão. Quim Nova 28:1038-1045

Croft BA (1990) Arthropod biological control agents and pesticides. Wiley, New York, $723 \mathrm{p}$

Cruz I, Figueiredo MLC, Oliveira CE, Vasconcelos CA (1999) Damage of Spodoptera frugiperda (Smith) in different maize genotypes cultivated in soil under three levels of aluminium saturation. Int J Pest Manag 45:293-296

Desneux N, Decourtye A, Delpuech J-M (2007) The sublethal effects of pesticides on beneficial arthropods. Annu Rev Entomol 52:81-106

Ferrer F (2001) Biological control of agricultural insects in Venezuela: advances, achievements, and future perspectives. Biocontrol News Inf 22:67-74

Folmar LC, Sanders HO, Julin AM (1979) Toxicity of the herbicide glyphosate and several of its formulations to fish and aquatic invertebrates. Arch Environ Contam Toxicol 8:269-278

Giesy JP, Dobson S, Solomon KR (2000) Ecotoxicological risk assessment for Roundup herbicide. Rev Environ Contam Toxicol 167:35-120

Giolo FP, Grützmacher AD, Procópio SO, Manzoni CG, Lima CAB, Nörnberg SD (2005) Seletividade de formulações de glyphosate a Trichogramma pretiosum (Hymenoptera: Trichogrammatidae). Planta Daninha 23:457-462

González CE, Zocco JL (1996) Controle integrado de Spodoptera frugiperda (Smith) utilizando Telenomus remus (Nixon) em Zea mays L. Rev Investig Agríc 1:201-219

Greene GL, Leppla NC, Dickerson WA (1976) Velvetbean caterpillar: a rearing procedure and artificial medium. J Econ Entomol 69:487-488

Guo L, Desneux N, Sonoda S, Liang P, Han P, Gao X-W (2013) Sublethal and transgenerational effects of chlorantraniliprole on biological traits of the diamondback moth Plutella xylostella. Crop Prot 48:29-34

Hassan SA (1992) Guideline for the evaluation of side-effects of plant protection product on Trichogramma cacoeciae. In: Hassan SA (ed) Guidelines for testing the effects of pesticides on beneficial organisms: description of test methods. IOBC/WPRS Bulletin 15: 18-39

Hassan SA, Bigler F, Blaisinger $P$, Bogenschütz $H$, Brun J, Chiverton $P$, Dickler E, Easterbrook MA, Edwards PJ, Englert WD, Firth SL, Huang P, Inglesfield C, Klingauf $F$, Kühner $C$, Ledieu MS, Naton E, Oomen PA, Overmeer WPJ, Plevoets P, Reboulet JN, Rieckmann W, Samsoe-
Petersen L, Shires SW, Staubli A, Stevenson J, Tuset JJ, Vanwetswinkel G, Van Zon AQ (1985) Standard methods to test the side-effects of pesticides on natural enemies of insects and mites developed by the IOBC/WPRS Working Group 'Pesticides and Beneficial Organisms'. EPPO Bull 15:214-255

Hassan SA, Halsall N, Gray AP, Kuehner C, Moll M, Bakker FM, Roembke J, Yousef A, Nasr F, Abdelgader HA (2000) A laboratory method to evaluate the side effects of plant protection products on Trichogramma cacoeciae Marchal (Hym., Trichogrammatidae). In: Candolfi MP, Blümel S, Forster R, Bakker FM, Grimm C, Hassan SA, Heimbach U, Mead-Briggs MA, Reber B, Schmuck R, Vogt H (eds) Guidelines to evaluate side-effects of plant protection products to non-target arthropods. IOBC/WPRS, Reinheim, pp 107-119

Hernández D, Ferrer F, Linares B (1989) Introdución de Telenomus remus Nixon (Hym.: Scelionidae) para controlar Spodoptera frugiperda (Lep.: Noctuidae) em Yaritagua, Venezuela. Agron Trop 39:199-205

Hinton HE (1981) Biology of insect eggs. Pergamon, Oxford, $473 p$

Howe CM, Berrill M, Pauli BD, Helbing CC, Werry K, Veldhoen N (2004) Toxicity of glyphosate-based pesticides to four North American frog species. Environ Toxicol Chem 23:1928-1938

Kim SW, Kwak JII, An Y-J (2013) Multigenerational study of gold nanoparticles in Caenorhabditis elegans: transgenerational effect of maternal exposure. Environ Sci Technol 47:5393-5399

Lorenzi H (2000) Plantas daninhas do Brasil: terrestres, aquáticas, parasitas, tóxicas e medicinais, 3rd edn. Instituto Plantarum, Nova Odessa, 425p

Mann RM, Bidwell JR (1999) The toxicity of glyphosate and several glyphosate formulations to four species of southwestern Australian frogs. Arch Environ Contam Toxicol 36:193-199

Manzoni CG, Grützmacher AD, Giolo FP, Härter WR, Müller C (2007) Seletividade de agrotóxicos usados na produção integrada de maçã para adultos de Trichogramma pretiosum. Pesq Agrop Brasileira 41: 1461-1467

Morales J, Gallardo S, Vásquez C, Ríos Y (2000) Patrón de emergência, longevidad, parasitismo y proporción sexual de Telenomus remus (Hymenoptera: Scelionidae) com relación al cogollero Del maíz. Bioagro 12:47-54

Nörnberg SD, Grützmacher AD, Giolo FP, Júnior GJE, Lima CAB, Grützmacher DD (2008) Seletividade de formulações de glyphosate aplicado nos estádios imaturos de Trichogramma pretiosum. Planta Daninha 26:611-617

Pak GA, van Dalen A, Kaashoek N, Dijkman H (1990) Host egg chorion structure influencing host suitability for the egg parasitoid Trichogramma Westwood. J Insect Physiol 36:869-875

Parra JRP (2001) Técnicas de criação de insetos para programas de controle biológico. FEALQ, Piracicaba, 134p

Planes L, Catalán J, Tena A, Porcuna JL, Jacas JA, Izquierdo J, Urbaneja A (2013) Lethal and sublethal effects of spirotetramat on the mealybug destroyer, Cryptolaemus montrouzieri. J Pest Sci 86:321-327

Pomari AF, Bueno AF, Bueno RCOF, Menezes Junior AO (2012) Biological characteristics and thermal requirements of the biological control agent Telenomus remus (Hymenoptera: Platygastridae) reared on eggs of different species of the genus Spodoptera (Lepidoptera: Noctuidae). Ann Entomol Soc Am 105:73-81

Prezotti L, Parra JRP, Vencovsky R, Dias CT, Cruz I, Chagas MCM (2002) Teste de vôo como critério de avaliação da qualidade de Trichogramma pretiosum Riley (Hymenoptera: Trichogrammatidae): Adaptação de metodologia. Neotrop Entomol 31:411-417

Rizzardi MA, Fleck NG, Agostinetto D, Balbinot Junior AA (2003) Ação de herbicidas sobre mecanismos de defesa das plantas aos patógenos. Cienc Rural 33:957-965

Routledge EJ, Sumpter JP (1996) Estrogenic activity of surfactants and some of their degradation products assessed using a recombinant yeast screen. Environ Toxicol Chem 15:241-248

Saber M, Abedi Z (2013) Effects of methoxyfenozide and pyridalyl on the larval ectoparasitoid Habrobracon hebetor. J Pest Sci 86:685-693 
Salt G (1938) Experimental studies in insect parasitism. VI. Host suitability. Bull Entomol Res 29:223-246

Santos KB, Meneguim AM, Santos WJ, Neves PMOJ, Santos RB (2010) Caracterização dos danos de Spodoptera eridania (Cramer) e Spodoptera cosmioides (Walker) (Lepidoptera: Noctuidae) a estruturas de algodoeiro. Neotrop Entomol 39:626-631

SAS Institute (2001) SAS user's guide: statistics: version 8.2. 6.ed. Cary. 201p

Schmidt JM (1994) Host recognition and acceptance by Trichogramma. In: Wajnberg E, Hassan SA (eds) Biological control with egg parasitoids. CAB International, Wallingford, pp 165-200

Schmidt JM, Smith JJB (1987) The measurement of exposed host volume by the parasitoid wasp Trichogramma minutum and effects of wasp size. Can J Zool 65:2837-2845

Shaner DL (2000) The impact of glyphosate-tolerant crops on the use of other herbicides and on resistance management. Pest Manag Sci 56: 320-326

Shapiro SS, Wilk MB (1965) An analysis of variance test for normality. Biometrika 52:591-611

Shrestha A, Steinhauer KM, Moretti ML, Hanson BD, Jasieniuk M, Hembree KJ, Wright SD (2014) Distribution of glyphosate-resistant and glyphosate-susceptible hairy fleabane (Conyza bonariensis) in central California and their phenological development. J Pest Sci 87: 201-209
Sohrabi F, Shishehbor P, Saber M, Mosaddegh MS (2013) Lethal and sublethal effects of imidacloprid and buprofezin on the sweetpotato whitefly parasitoid Eretmocerus mundus (Hymenoptera: Aphelinidae). Crop Prot 45:98-103

Stinner RE (1977) Efficacy of inundative releases. Annu Rev Entomol 22: 515-531

Tan Y, Biondi A, Desneux N (2012) Assessment of physiological sublethal effects of imidacloprid on the mirid bug Apolygus lucorum (MeyerDür). Ecotoxicology 21:1989-1997

Travlos IS, Chachalis D (2013) Relative competitiveness of glyphosateresistant and glyphosate-susceptible populations of hairy fleabane, Conyza bonariensis. J Pest Sci 86:345-351

van der Werf HMG (1996) Assessing the impact of pesticides on the environment. Agric Ecosyst Environ 60:81-96

Wijnands FG (1997) Integrated crop protection and environment exposure to pesticides: methods to reduce use and impact of pesticides in arable farming. Eur J Agron 7:251-260

Williams GM, Kroes R, Munro IC (2000) Safety evaluation and risk assessment of the herbicide Roundup and is active ingredient, glyphosate, for humans. Regul Toxicol Pharmacol 31:117-165

Yu SJ (1987) Biochemical defense capacity in the spined soldier bug (Podisus maculiventris) and its lepidopterous prey. Pestic Biochem Physiol 28:216-223 